\title{
BEBERAPA TUMBUHAN OBAT ASAL KALIMANTAN TIMUR SEBAGAI SUMBER SAPONIN POTENSIAL
}

\author{
Laode Rijai \\ Laboratorium Penelitian Kefarmasian Fakultas Farmasi Universitas Mulawarman \\ email : najwankhanrjai@yahoo.co.id
}

\begin{abstract}
Saponin is a class of natural compounds that have activity that is strongly associated with utilization in pharmacy. Exploration has been carried out against a number of secondary metabolite content of medicinal plants in East Kalimantan and some of them found to contain saponins. Plants were found to contain saponins and are considered potential Kokang leaf (Lepisanthes amoena), Kesumbakeling leaf (Bixa orellana, L), Belimbing Wuluh leaf (Averrhoa bilimbi L.), Sugi Gadjah leaf (Hyptis capitata), Karamunting leaf (Melastoma malabathricum L), Cempedak bark (Artocarpus champeden), Wijaya Kusuma leaf (Epiphyllum oxipetalum), Langsat seeds (Lansium domesticum), ekor kucing leaf (Acalypha hispida), Kelor bark (Moringa oleifera), Jarong leaf (Stachytarpheta mutabilis), Miana leaf (Coleus atropureus), Jengger Ayam leaf (Celosia cristata), and fruit of Libo (Ficus vargelata).
\end{abstract}

Key words : East borneo medicinal plants, saponins

\begin{abstract}
Abstrak
Saponin adalah golongan senyawa alami yang memiliki aktivitas yang sangat terkait dengan pemanfaatan dalam bidang farmasi. Telah dilakukan eksplorasi kandungan metabolit sekunder terhadap sejumlah tumbuhan obat yang ada di Kalimantan Timur dan beberapa diantaranya terbukti mengandung saponin. Tumbuhan-tumbuhan yang terbukti mengandung sponin dan dianggap potensial adalah daun Kokang (Lepisanthes amoena), daun Kesumbakeling (Bixa orellana, L), daun Belimbing Wuluh (Averrhoa bilimbi L.), daun Sugi Gadjah (Hyptis capitata), daun Karamunting (Melastoma malabathricum L), kulit batang Cempedak (Artocarpus champeden), daun Wijaya Kusuma (Epiphyllum oxipetalum), biji Langsat (Lansium domesticum), daun ekor kucing (Acalypha hispida), Kulit Batang Kelor (Moringa oleifera), daun Jarong (Stachytarpheta mutabilis), daun Miana (Coleus atropureus), daun Jengger Ayam (Celosia cristata), buah Libo (Ficus vargelata).
\end{abstract}

Kata Kunci: Tumbuhan Obat Kaltim; Saponin

\section{PENDAHULUAN}

Saponin adalah suatu golongan senyawa alami yang sangat potensial karena memiliki sekitar 25 jenis aktivitas biologi yang berpotensi untuk dimanfaatkan dalam bidang farmasi yaitu obat, makananminuman, dan kosmetik [2]. Senyawa alami saponin bersifat polar sehingga larut baik dalam air. Strukturnya yang mengikat karbohidrat memudahkan larut dalam air sehingga mudah penanganannya jika akan dimanfaatkan dalam bidang sediaan farmasi. Telah banyak ditemukan di Indonesia tumbuhan-tumbuhan yang terbukti mengandung saponin pada 
rendamen yang cukup tinggi. Tumbuhantumbuhan tersebut dipandang sangat penting dan strategis untuk dimanfaatkan dalam bidang kefarmasian. Tindak lanjut yang dapat dilakukan terhadap tumbuhantumbuhan yang mengandung saponin adalah (a) ekstraksi spesifik saponin melalui teknik fraksinasi sederhana dan (b) isolasi dan elusidasi struktur jenis senyawa saponin dari ekstrak spesifik tersebut. Ekstrak kasar saponin sangat berguna sebagai bahan aktif untuk suatu sediaan tertentu sesuai dengan aktivititas biologi yang dimilikinya. Nilai ekonomi ekstrak saponin (tanpa campuran golongan lain) juga cukup tinggi yaitu berkisar antara 1 s/d 1,5 jt setiap 100 g [1]. Ekstraksi spesifik saponin mudah dilakukan terhadap tumbuhan atau bagian tumbuhan yang teridentifikasi secara kimia mengandung saponin. Kalimantan Timur yang terkenal memiliki keanekaragaman hayati yang banyak terutama tumbuhan sangat menarik untuk melakukan eksplorasi kimia saponin. Sejak tahun 2007 telah dilakukan eksplorasi tumbuhan obat yang ada di Kalimantan Timur dan telah ditemukan sekitar 300 jenis yang diklaim masyarakat sebagai tumbuhan obat [3].

Penetapan tumbuhan sebagai tumbuhan obat dalam penelitian tersebut berdasarkan pada pengalaman masyarakat secara tradisional tanpa melakukan verifikasi laboratorium. Tumbuhan-tumbuhan tersebut di antaranya telah dilakukan skrining bioaktivitas (aktivitas biologi) terhadap beberapa bioindikator dan juga telah dilakukan skrining kimia termasuk saponin. Temuan saponin terhadap beberapa tumbuhan obat tersebut menggambarkan potensi untuk pengembangannya terutama dalam bidang kemanfaatan dan penelitian. Kemanfaatan saponin dalam bidang kefarmasian digambarkan oleh multibioaktif yang telah diuraikan sebelumnya, sedangkan kemanfaatan dalam bidang penelitian adalah prospek menemukan senyawa saponin baru sebagai akibat keragaman struktur saponin yang sangat banyak.

Molekul saponin yang merupakan gabungan antara steroid atau triterpen dengan satu atau lebih molekul atau jenis monosakarida telah mengakibatkan memiliki ujung sangat polar dan ujung polaritas rendah. Fenomena perbedaan polaritas ujung molekul yang ekstrim tersebut telah menyebabkan saponin memiliki sifat aktif tegangan permukaan sehingga mengahasilkan busa dalam pelarut air. Sifat aktif tegangan permukaan tersebut salah satu penyebab ia memiliki keragaman aktivitas biologi.

Perbedaan polaritas ujung molekul yang ekstrim tidak menyebabkan saponin bersifat non-polar bahkan memiliki polaritas tinggi yang pada umumnya identik dengan polaritas dengan pelarut organik dari $n$-butanol ke atas, meskipun di antaranya ada yang sesuai dengan polaritas etilasetat. Karena itu senyawa saponin sebagai bahan aktif bahan farmasi sangat potensial untuk suatu sediaan farmasi karena memiliki polaritas yang tinggi sehingga absorabsi dan distribusi atau farmakokinetiknya dalam sel cukup baik untuk suatu produk farmasi untuk kesehatan.

Berdasarkan uraian tersebut, maka artikel ini mengemukakan beberapa tumbuhan obat asal Kalimantan Timur sebagai sumber saponin. Tumbuhan-tumbuhan tersebut telah dilakukan skrining saponin secara sederhana. Hasil penelitian ini berguna untuk tindakan selanjutnya sehingga potensi ekonomi tumbuhan dapat ditingkatkan. Penelitian ini memberikan nilai manfaat dalam ilmu pengetahuan, lingkungan, dan ekonomi. Manfaat ilmu pengetahuan terkait dengan prospektif 
penemuan senyawa baru jika kelak nanti dilakukan penelitian isolasi dan elusidasi struktur senyawa saponin dari berbagai tumbuhan tersebut, manfaat ekonomi terkait dengan peningkatan nilai ekonomi jika kelak nanti dilakukan penelitian untuk menghasilkan produk farmasi, sedangkan manfaat lingkungan terkait dengan usaha pelestarian tumbuhan jika manfaat ekonomi dan ilmu pengetahuan tercapai sehingga memungkinkan pelaksanaan budidaya oleh masyarakat yang tertarik terhadap dua manfaat tersebut.

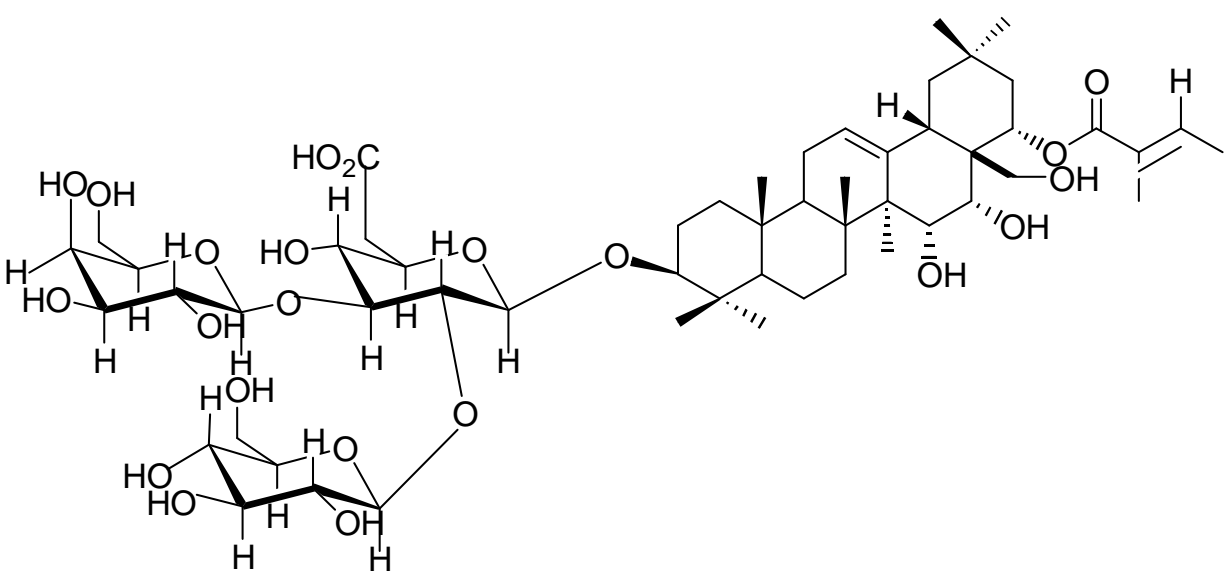

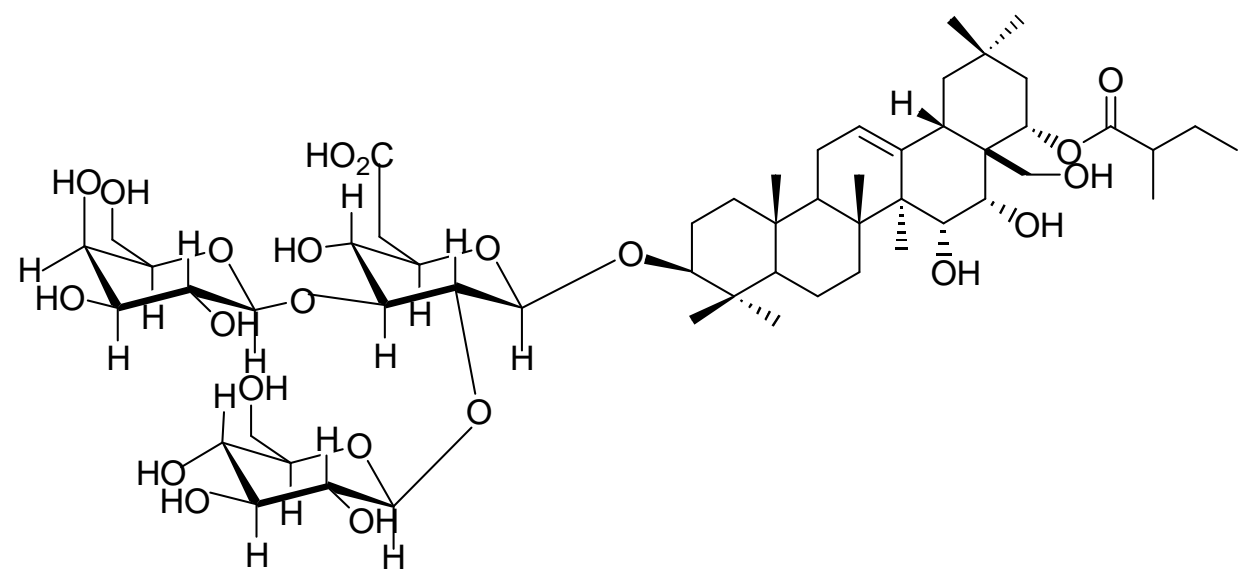

Gambar 1. Contoh struktur saponin dari biji Chydenanthus excelsus (Rijai, 2004)

\section{METODE PENELITIAN}

Identifikasi saponin terhadap berbagai tumbuhan obat asal Kalimantan Timur dilakukan secara sederhana yaitu metode skrining. Sampel tumbuhan sebagai obyek penelitian yaitu sejumlah tumbuhan obat yang dieksplorasi sejak tahun 2007 hingga 2010 di beberapa daerah di Kalimantan Timur. Tumbuhan obat tersebut berasal dari Kabupaten Kutai Barat, Kabupaten Malinau, Kabupaten Kutai Timur, dan Kabupaten Penajam Paser Utara (PPU). Seluruh bagian tumbuhan dilakukan skrining saponin, tetapi yang dilaporkan hanya yang terbukti mengandung saponin yang cukup dominan. Teknik skrining yang dilakukan adalah setiap bagian tumbuhan dihaluskan dengan berbagai cara sesuai dengan bagian tumbuhan yang diskrining, antara lain dengan teknik gerus dan 
blander. Bagian tumbuhan yang telah dihaluskan selanjutnya ditambahkan aquades dalam tabung reaksi lalu dikocok hingga menimbulkan busa (jika mengandung saponin). Busa yang terbentuk diukur tingginya dan dibiarkan paling singkat 30 menit. Untuk memastikan busa yang timbul merupakan busa saponin atau protein maka terhadap busa tersebut diteteskan larutan $\mathrm{HCl} 0,1 \mathrm{~N}$. Jika busa menjadi hilang setelah penambahan larutan $\mathrm{HCl}$ maka busa tersebut berasal dari protein atau golongan lainnya sebagai akibat terjadikan ikatan kimia antara ion $\mathrm{Cl}$ dengan ion dalam protein.

\section{HASIL DAN PEMBAHASAN}

Sejak tahun 2007 sampai sekarang inventarisasi tumbuhan obat di Kalimantan Timur terus dilakukan sebagai kegiatan utama kelompok Peneliti Bahan Alam Fakultas Farmasi. Pendekatan inventarisasi tumbuhan obat berdasarkan pada pengalaman masyarakat di pedalaman Kalimantan Timur. Fenomena menarik yang ditemukan terkait dengan pengalaman masyarakat dalam memanfaatkan tumbuhan obat adalah suatu tumbuhan dianggap tumbuhan obat oleh masyarakat pada kampung tertentu, sedangkan masyarakat kampung lainnya justru tumbuhan tersebut dianggap sebagai gulma atau tumbuhan beracun. Para peneliti mencatat semua kejadian tersebut, dan terhadap seluruh tumbuhan yang ditemukan akan diteliti satu persatu mulai dari skrining metabolit sekunder kandungannya, skrining bioaktif, hingga pada isolasi senyawa dan pengujianpengujian farmakologi untuk kearah pemanfaatan dalam bidang farmasi. Tumbuhan obat hasil eksplorasi di Kalimantan Timur beberapa di antaranya teridentifikasi mengandung saponin.

Beberapa Tumbuhan tersebut ditunjukkan pada Tabel 1. Keempatbelas tumbuhan tersebut memiliki potensi dalam bidang farmasi karena seluruh saponin yang telah ditemukan selama ini terbukti memiliki bioaktif dan telah ditemukan 25 jenis bioaktif yang telah dimiliki oleh senyawasenyawa saponin [2]. Aktivitas biologi yang telah dikenal dimiliki oleh senyawasenyawa golongan saponin ditunjukkan pada Tabel 2. Tumbuhan-tumbuhan obat telah terbukti mengandung saponin seperti yang ditunjukkan pada Tabel 1 berpotensi untuk memiliki satu atau lebih aktivitas biologi yang ditunjukkan oleh Tabel 2 . Penelitian lanjutan terhadap tumbuhantumbuhan tersebut sangat diperlukan untuk memastikan yang lebih akurat tentang adanya saponin dalam beberapa bagian tumbuhan tersebut. Penelitian saponin dapat menghasilkan tiga manfaat sekaligus yaitu manfaat ekonomi, ekologi, dan ilmu pengetahuan. Manfaat ekonomi terhadap penelitian saponin adalah ditemukannya saponin dalam tumbuhan, sedangkan saponin memiliki 25 kemungkinan bioaktivitas dan bioaktivitas-bioaktivitas tersebut memiliki kemanfaatan dalam bidang farmasi sehingga berpotensi pemanfaatannya dalam bidang kesehatan. Pemanfaatan tumbuhan dalam bidang kesehatan baik itu sebagai obat maupun untuk peningkatan kualitas kesehatan akan memberikan nilai ekonomi yang sangat tinggi terhadap tumbuhan tersebut.

Selanjutnya, manfaat ekologi bermakna bahwa jika telah ditemukan manfaat ekonomi suatu tumbuhan maka kemungkinan pembudidayaan tumbuhantumbuhan tersebut dapat dilaksanakan secara serta merta oleh masyarakat sehingga tumbuhan-tumbuhan yang selama ini tidak termanfaatkan menjadi terlindungi dan terdomestifikasi.

Kegiatan tersebut merupakan program pengelolaan lingkungan atau ekologi. Selanjutnya manfaat penelitian saponin 
dalam ilmu pengetahuan terkait dengan temuan-temuan baru. Saponin memiliki keragaman jenis yang sangat tinggi sehingga berpeluang untuk menmukan senyawa dan akitvitas senyawa yang baru dari setiap kegiatan penelitian saponin. Temuan senyawa baru atau kemanfaatan baru suatu saponin merupakan perkembangan ilmu pengetahuan.

Tabel 1. Beberapa Tumbuhan Obat yang ditemukan di Kalimantan Timur yang terbukti mengandung saponin berdasarkan hasil skrining kimia

\begin{tabular}{clc}
\hline No & \multicolumn{1}{c}{ Nama Tumbuhan } & Bagian Tumbuhan yang mengandung Saponin \\
\hline 1 & Kokang (Lepisanthes amoena) & daun \\
2 & Kesumbakeling (Bixa orellana, L) & daun \\
3 & Belimbing Wuluh (Averrhoa bilimbi L.) & daun \\
4 & Sugi Gadjah (Hyptis capitata), & daun \\
5 & Karamunting (Melastoma malabathricum L), & daun \\
6 & Cempedak (Artocarpus champeden), & kulit batang \\
7 & Wijaya Kusuma (Epiphyllum oxipetalum) & daun \\
8 & Langsat (Lansium domesticum), & biji \\
9 & Ekor kucing (Acalypha hispida) & daun \\
10 & Kelor (Moringa oleifera), & Kulit batang \\
11 & Jarong (Stachytarpheta mutabilis) & daun \\
12 & Miana (Coleus atropureus), & daun \\
13 & Jengger Ayam (Celosia cristata) & daun \\
14 & Libo (Ficus vargelata) & buah \\
\hline
\end{tabular}

Sumber: Rijai (2008)

Tabel 2. Beberapa Jenis Aktivitas Biologi yang telah terbukti dimiliki Senyawa golongan Saponin

\begin{tabular}{cl}
\hline No & \multicolumn{1}{c}{ Beberapa Aktivitas Biologi yang terbukti dimiliki Senyawa Golongan Saponin } \\
\hline 1 & Antibacterial activity \\
3 & Fungicidal activity \\
4 & Antiviral activity \\
5 & Antotoxic dan antitumor activity \\
6 & Piscicidal activity \\
7 & Molluscicidal activity \\
8 & Incecticidal and antifeedant activity \\
9 & Anthelmintic activity \\
10 & Expectorant and antitussive activity \\
11 & Diuretic activity \\
12 & Cholesterol metabolism (penurunan) \\
13 & Cardiovascular activities \\
14 & Antiarrhytlumic action \\
15 & Vasodilatory action \\
16 & Effects on the adrenocorticotropic system \\
17 & Antiinflammatory; antiexudative and antioedematous activities \\
18 & Effects on capillary fragility and venous stasis/venous insufficiency \\
19 & Antiulcer activity \\
20 & Analgesic activity \\
21 & Antipyretic activity \\
22 & Immunomodulation \\
23 & Adaptogenic activity \\
24 & Sedative activity \\
25 & Miscellaneous activities \\
Sumber: Hostettmann dan Marston, 1955)
\end{tabular}


Dengan demikian temuan tumbuhantumbuhan obat yang memiliki kandungan saponin yang cukup dominan tersebut memberikan peluang untuk diadakan penelitian selanjutnya sehingga manfaat ekonomi, ekologi, dan ilmu pengetahuan tumbuhan-tumbuhan tersebut dapat terungkap atau ditemukan.

\section{KESIMPULAN}

Kesimpulan penelitian ini adalah:

a. Telah ditemukan 14 jenis tumbuhan obat di Kalimantan Timur yang mengandung senyawa golongan saponin yang cukup dominan

b. Keempatbelas jenis tumbuhan obat tersebut pasti memiliki satu atau lebih aktivitas biologi yang dikenal dalam bidang farmasi

\section{SARAN-SARAN PENELITIAN}

Saran untuk kelanjutan penelitian saponin adalah

1. Pelaksanaan penelitian tentang pengujian ekstrak saponin dari 14 jenis tumbuhan obat tersebut terhadap 25 jenis aktivitas biologi yang telah terbukti dimiliki oleh senyawa-senyawa golongan saponin

2. Pelaksanaan penelitian tentang isolasi dan elusidasi struktur serta pengujian bioktivitas senyawasenyawa saponin dari 14 jenis tumbuhan obat tersebut

3. Kegiatan eksplorasi kimia termasuk saponin terus dilakukan terhadap berbagai tumbuhan yang ada di Kalimantan Timur yang dianggap obat atau tidak dianggap obat oleh masyarakat

\section{DAFTAR PUSTAKA}

1. Bayer, G. 2006. Economy of Natural Products. Merck. German.

2. Hostettmann, K.; \& Marston, A. 1955. Saponins: Chemistry and Pharmacology of Natural Products. In Great Britain at the University Press, Cambridge.

3. Rijai, L. 2008. Eksplorasi Kimia terhdap Tumbuhan Obat yang ada di Kalimantan Timur, LEMLIT-UNMUL, Samarinda

4. Rijai, L. 2004. Isolasi dan Elusidasi Struktur beberapa Senyawa Saponin dari biji Chydenanthus excelsus 